\title{
Valorization of Palm Empty Fruit Bunch Waste for Syngas Production Through Gasification
}

\author{
Nabila Aprianti ${ }^{1}$, Muhammad Faizal2², Muhammad Said ${ }^{2}$, Subriyer Nasir ${ }^{2}$ \\ 1 Doctoral Program of Environmental Science, Graduate School, Universitas Sriwijaya, Jl. Padang Selasa \\ No. 524 Bukit Besar, Palembang, South Sumatera, Indonesia \\ 2 Chemical Engineering Department, Faculty of Engineering, Universitas Sriwijaya, J. Raya \\ Inderalaya - Prabumulih Km. 32 Ogan Ilir, South Sumatera, Indonesia \\ * Corresponding author's e-mail: muhammadfaizal@unsri.ac.id
}

\begin{abstract}
The rapid progress of the CPO industry in Indonesia is not in line with good waste management and utilization. Palm empty fruit bunch, as the first waste from the CPO production process in Indonesia, is mostly piled on the ground. Palm empty fruit bunch must be processed to reduce pollution and increase its use-value. This study aimed to convert oil palm empty fruit bunches solid waste through the gasification process using Indonesia's natural zeolite into synthesis gas. Gasification takes place at $350-550^{\circ} \mathrm{C}$ by added $12.5 \%$ wt zeolite using a modified updraft gasifier. Good results were achieved at $550^{\circ} \mathrm{C}$ with a gas composition of $22.64 \%$ vol $\mathrm{CH}_{4}, 29.22 \%$ vol $\mathrm{CO}$, and $3.4 \%$ vol $\mathrm{H}_{2}$. The gasification efficiency is evaluated through carbon conversion efficiency (CCE) and cold gas efficiency (CGE). Both the highest CCE and CGE were found at $550^{\circ} \mathrm{C}$ by $95.74 \%$ and $81.65 \%$ respectively. The results showed that the gasification temperature has the greatest influence in driving higher carbon conversion to syngas and palm empty fruit bunches are very suitable for conversion into environmentally friendly syngas in the CPO industry.
\end{abstract}

Keywords: catalytic, palm mill, updraft gasifier, zeolite

\section{INTRODUCTION}

Indonesia is one of the largest palm oil producing countries in the world. In 2018, the Indonesia's total crude palm oil (CPO) production was estimated at 36.96 million tons with an area of 12.76 million Ha (Shahputra and Zen, 2018). Apart from the condition of the soil and the supporting environmental factors (Ooi et al., 2017), the land conversion to oil palm plantations is a major cause of the rapid development of the palm oil industry (Afriyanti, Kroeze, and Saad, 2016). Even the Indonesian government supports the use of biofuel from palm oil (Putrasari et al., 2016). Of course, the palm oil production is predicted to continue to increase along with the expansion of the plantation land and the effort to change the type of fuel (Yoo et al., 2019).
The increase in the palm oil industry has resulted in an increase in the amount of palm oil biomass waste. The palm oil industry produces $20-22 \%$ CPO from every ton of fresh fruit bunches (Liew et al., 2018). The rest of the oil palm that cannot produce CPO consists of $23-25 \%$ empty fruit bunches, $13-15 \%$ fibers and 5-6\% palm shells (Li and Chen, 2018). Umar, Urmee, and Jennings (2017) confirmed that by 2020 , there will be 100 million tons of dry biomass solid waste. The oil palm industry returns empty fruit bunches to plantations to be used as fertilizer, but not all CPO industries do it. Palm empty fruit bunches have been piled on the ground for a long time, even up to several years. The CPO industry located near peatlands makes palm empty fruit bunches vulnerable to burning. The accumulation of methane in oil palm empty fruit bunches also adds to the air and soil pollution. Some of 
industry is used palm empty fruit bunch as boiler fuel (You et al., 2017) . However, direct combustion to heat the boiler will release the greenhouse gases into the air (Kodir et al., 2017).

A large amount of biomass can be utilized as a source of renewable energy (Faizal, 2017; Amrullah and Matsumura, 2018). Various conversion methods have been developed to utilize CPO industry biomass waste, especially palm empty fruit bunches (PEFB). Gasification is one method of the thermochemical conversion process that converts raw materials into energy in the form of a gas called syngas (Soria-Verdugo et al., 2019) . Gasification has the potential to solve several problems at once, namely the energy crisis, biomass waste management and greenhouse gas emission. The advantage of converting biomass through gasification is to produce synthesis gas that can be used as fuel to drive generators to produce electricity (Patra and Sheth, 2015), produce less $\mathrm{CO}_{2}$ (Umeda et al., 2019), and can use biomass in various forms both dry and wet (Zhang et al., 2019). The gasified gas consists of the main composition of $\mathrm{CO}, \mathrm{H}_{2}, \mathrm{CH}_{4}$ and small amount of $\mathrm{CO}_{2}$ (Hossain, 2018). However, the research on using palm empty fruit bunches as raw material to produce synthesis gas is still limited (Mahlia et al., 2019).

The gasification of oil palm empty fruit bunches that has been done before using supercritical water and POME by Sivasangar et al. (Sivasangar et al., 2015) which shows an increase in hydrogen along with reaction time. The gasification of oil palm empty fruit bunches using steam gasification medium was carried out by $\mathrm{Li}$ and Chen (2018) who stated that the $\mathrm{H}_{2} / \mathrm{CO}$ ratio was influenced by temperature. Co-gasification involving oil palm empty fruit bunches with biochar from oil palm empty fruit bunches was carried out by Monir et al. (2018) at high temperature and pressure. The result, $\mathrm{CO}$ is the highest gas in syngas but there is still $\mathrm{CO}_{2}$ which is quite high.

The syngas produced in previous studies still contains $\mathrm{CO}_{2}$. Even in small amounts, the ability to burn the synthesis gas will decrease (Sarafraz et al., 2019) so it still has to be separated. The separation of $\mathrm{CO}_{2}$ using a series of equipment will increase production costs. Now, several studies have been carried out to improve the quality of synthesis gas, including the use of catalysts (Zhou et al., 2019), mixing other raw materials (Monir et al., 2018; Cabuk et al., 2019)], gasifier selection and modification (Sazali, Al-attab, and
Zainal, 2019), selection of the gasification medium (Shayan, Zare, and Mirzaee, 2018), and gas purification (Zhang et al., 2018).

In this study, the use of catalysts was chosen to improve the quality of gasification. Indonesia has abundant alumina-based catalysts. Natural zeolite has been widely used as a catalyst in pyrolysis (Gurevich, Bonelli, and Cukierman, 2017; Miandad et al., 2017) and cracking (Sihombing et al., 2020), but has not been popular for the gasification process. However, the use Indonesian natural zeolite to produce synthesis gas through gasification from palm oil biomass waste has never been done. The purpose of this research was to convert palm empty fruit bunch into syngas through catalytic gasification.

\section{MATERIALS AND METHOD}

\section{Raw materials and catalyst preparation}

Palm empty fruit bunches (PEFBs) were gathered from one of the palm oil mills in South Sumatera, Indonesia. The PEFB produced as byproduct from the CPO process after the fresh bunches were removed. The PEFBs were manually chopped into a part of the pieces. The PEFB had approximately $70 \%$ moisture in all around bunches. The PEFBs were dried first under the sun until the water content decreased by about $50-60 \%$. Then, the remainder was dried at $105^{\circ} \mathrm{C}$ for 2 hours in oven. Finally, the size of PEBs was less than $5 \mathrm{~cm}$.

Zeolite was obtained as natural zeolite from district of Sarolangun, Jambi, Indonesia. Zeolite in a granular form was used as catalyst for gasification process. The preparation of zeolite was performed by thermal activation at $400^{\circ} \mathrm{C}$ for 3 hours using thermolyne benchtop muffle furnace (Thermo scientific thermolyne F48050-33) before directly used in gasifier.

\section{Materials characterization}

The palm empty fruit bunch samples were characterized by proximate and ultimate analysis (the as-received) refers to a standard test method (ASTM D) using a thermogravimetric analyzer (Shimadzu TGA-50). In turn, the natural zeolite (NZ) was characterized by X-Ray diffraction (XRD) and Fourier Transfrom Infra-Red (FTIR) called natural zeolite thermal activated (NZTA). 
The analysis of XRD was performed using the Rigaku Miniflex 600 X-Ray diffractometer with $\mathrm{CuK}$ radiation at $30 \mathrm{kV}$ and $10 \mathrm{~mA}$. The analysis was measured with speed of scanning $10^{\circ} \%$ min and recorded at 2 theta range about 5 to $80^{\circ}$. The XRD analysis aimed to analyze the structure properties of zeolite as one of type clay mineral. The FTIR analysis was conducted in order to identify the functional group of the zeolite by using a FTIR Spectrometer (Thermo Scientific Nicolet iS10 FT-IR Spectrometer). The sample was run from wavenumber 400 to $4000 \mathrm{~cm}^{-1}$.

\section{Gasification process and apparatus}

The catalytic gasification of PEFB was carried out in the modified updraft gasifier (Figure 1) using air as the gasifying agent. In the updraft gasifier, the raw material is fed from the top of the gasifier, while the gasification agent is fed at the bottom of the gasifier. The main components of the gasifier include the reaction chamber, heating system, electric motor and mixer which are connected to the clutch drive and speed controller, condenser and water cooler, and the gasification gas discharge system. The gasification reactor is made of stainless steel (SUS316). The gasifier was set at low temperature $400^{\circ} \mathrm{C}, 450^{\circ} \mathrm{C}, 500^{\circ} \mathrm{C}$, and $550^{\circ} \mathrm{C}$. The sample was taken at each temperature. The gas product came out the gasifier was analyzed by using Gas Chromatography (Shimadzu GC-2014) in order to identify the composition of the gases.

The PEFB was first fed into the gasifier (R-01) through the feeding hopper (FH-01). The temperature of the gasifier is adjusted as desired. The reactor is equipped with a nozzle heater. During the experiment, the temperature was measured with a K-type thermocouple equipped with a stainless steel probe sensor. The temperature of the biomass sample can be controlled by the system through a control panel (CP-01). After the condition is reached, air is flowed using a blower (F-01). The reaction lasts up to 30 minutes until the gas was produced and flowed first through a cooling system consisting of a condenser (CD-01), a water pump (P-01), and a cooling water reservoir (CW$01)$ as a supply for the condenser. The gas product flow was separated by flash tanks (FT-01). The outgoing gas at the top was then collected by means of a gas sampling bag (GB-01). The liquid product which is suspected as a by-product in the form of tar was accommodated in a separate tube (LC-01).

\section{Analysis}

The high heating value (HHV) and low heating value (LHV) of the syngas were calculated with Eq. (1) and (2) (Monir et al., 2018).

$$
\begin{aligned}
& \operatorname{LHV}_{\text {gas }}=(30 \times C O\left.+25,7 \times \mathrm{H}_{2}+85,4 \times \mathrm{CH}_{4}\right) \\
& \times 0,0042 \\
& \mathrm{HHV}_{\text {gas }}=\left(\mathrm{H}_{2} \times 30,52+\mathrm{CO} \times 30,18+\mathrm{CH}_{4} \times 95\right) \\
& \times 0,0041868
\end{aligned}
$$

In turn, the carbon conversion efficiency (CCE) and cold gas efficiency (CGE) were calculated with Eq (3) and (4) (Chew et al., 2020).

$$
\operatorname{CCE}(\%)=\frac{\% \mathrm{C}_{\text {gas }}}{\% \mathrm{C}_{\text {biomass }}} \times 100
$$

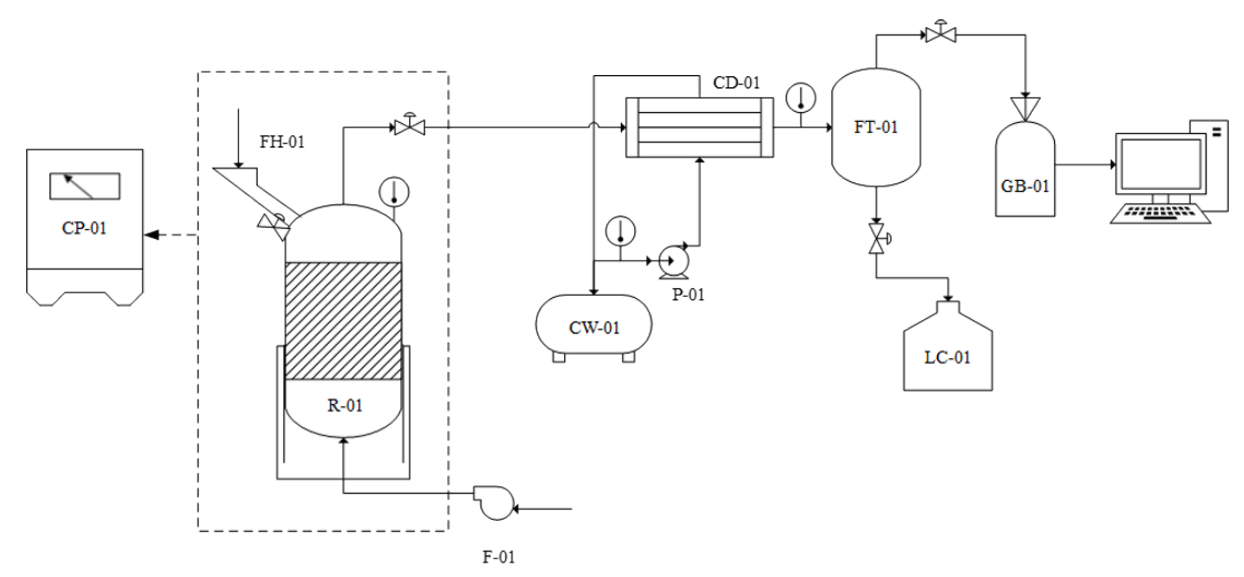

Figure 1. Schematic diagram of PEFB gasification 


$$
\operatorname{CGE}(\%)=\frac{\mathrm{LHV}_{\text {gas }}}{\mathrm{LHV}_{\text {biomass }}} \times 100
$$

\section{RESULTS AND DISCUSSION}

\section{PEFB characterizations}

The characteristics of PEFB are known through proximate and ultimate analysis (Table 1). As a comparison, the results of the characterization of PEFB were compared with the results with other palm oil solid waste such as palm kernel shells (PKS) and palm oil mesocarp fibers (PMF) from previous studies. The PEFB volatile matter in this study showed a lower value than the previous research on PEFB and other palm oil solid wastes. Volatile matter in biomass tends to be higher than coal which makes the conversion to gas easier.

Wet biomass requires a longer residence time and more energy for drying before the gasification stage. The moisture content of the raw material increases due to a decrease in temperature in the oxidation zone, so that the overall gasification efficiency decreases resulting in low hydrocarbon conversion from the pyrolysis zone. In water gas shift reaction and steam formation, the moisture from raw materials is needed to produce high syngas products. The PEFB from this study showed the highest ash content, especially compared to PMF. High ash content can reduce the heating value of biomass, because it reduces the percentage of fixed carbon content in biomass. Fixed carbon depends on the water content, ash content, and volatile matter content of raw materials. If the water content, ash content, and volatile matter level becomes lower, then the bound carbon content will be higher and the heating value will also increase. Compared to the PEFB from previous studies, fixed carbon from PEFB in this study was higher at $21.63 \%$.

On the basis of the ultimate analysis, PEFB has oxygen, carbon, hydrogen, nitrogen, and sulfur content of $29.65 \%, 42.12 \%, 3.77 \%, 0.16 \%$, and $0.06 \%$ respectively. Compared to other palm oil waste, PEFB in this study has the lowest oxygen and carbon content. This result has a negative impact on HHV because of higher oxygen concentrations (carbon-oxygen bonds are likely to reduce the calorific value of PEFB. The sulfur content in the PEFB in this study is much lower than the PEFB in previous studies. Because nitrogen and sulfur are in small amounts, then overall PEFB can be considered environmentally friendly. The ratios of $\mathrm{H} / \mathrm{C}$ and $\mathrm{O} / \mathrm{C}$ of PEFB in this study are 1.07 and 0.63 , respectively. The molecular formula of PEFB based on the main atom can be written as $\mathrm{CH}_{1.07} \mathrm{O}_{0.63}$, PEFB has HHV 16.47 MJ/kg, a slightly lower value than reported in the literature for wood (Pino, Buitrago-Sierra, and López, 2019; Chang et al., 2018; Khanday, Kabir, and Hameed, 2016), but the value is consistent with higher oxygen and lower carbon content in PEFB, although the heating value PEFB is small compared to the calorific value of coal, PEFB is still a potential solid fuel to produce renewable energy.

Table 1. Characterization of palm oil solid waste

\begin{tabular}{|c|c|c|c|c|}
\hline Properties & $\begin{array}{c}\text { PEFB } \\
\text { (this research) }\end{array}$ & $\begin{array}{c}\text { PEFB } \\
\text { (Pino, Buitrago-Sierra, } \\
\text { and López, 2019) }\end{array}$ & $\begin{array}{c}\text { PKS } \\
\text { (Chang et al., 2018) }\end{array}$ & $\begin{array}{c}\text { PMF } \\
\text { (Khanday et al., 2016) }\end{array}$ \\
\hline \multicolumn{5}{|c|}{ Proximate analysis (\%wt) } \\
\hline Ash content & 15.31 & 3.1 & 2.25 & 1 \\
\hline Volatile matter & 54.13 & 76 & 74.61 & 67 \\
\hline Fixed carbon & 21.63 & 17 & 23.14 & 28 \\
\hline Calorific value (MJ/kg) & 16.47 & 19 & 20.14 & 17 \\
\hline \multicolumn{5}{|l|}{ Ultimate analysis (\%wt) } \\
\hline Carbon & 42.12 & 48 & 49.50 & 45 \\
\hline Hydrogen & 3.77 & 6.7 & 5.90 & 11 \\
\hline Nitrogen & 0.16 & 1.0 & 0.47 & 1 \\
\hline Oxygen & 29.65 & 44 & 42.30 & 42 \\
\hline Sulphur & 0.06 & 0.34 & 0.03 & 1 \\
\hline
\end{tabular}




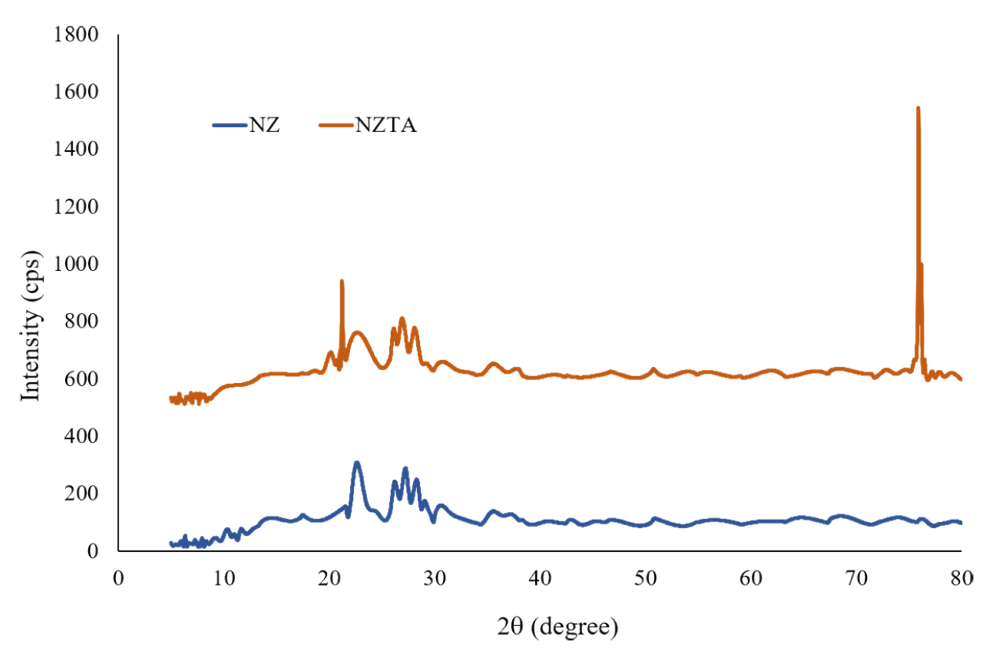

Figure 2. XRD pattern of NZ and NZTA

\section{Zeolite characterization}

$\mathrm{XRD}$ is an analysis technique used to determine the change of the layer space in clay mineral. The XRD analysis in this study was performed in order to assign the crystal structure of the natural zeolite and thermal activated zeolite. Figure 2 showed the XRD pattern of natural zeolite and thermal activated zeolite recorded from $5-80^{\circ}$. On the basis of the results of the work (Nizami et al., 2016), in the range of peak $20^{\circ}$ to $30^{\circ}$ recorded at $2 \theta$ there is an indication of zeolite from alumina silicate mineral in the presence of other elements such as $\mathrm{Mg}, \mathrm{Fe}$ and $\mathrm{Na}$, etc. (Naghizadeh et al., 2017). After thermal activation, the natural zeolite showed significant changes from the XRD patterns. At peaks of $20^{\circ}$ to $40^{\circ}$, peak alignment has occurred. This is thought to be due to the loss of several compounds during the activation. At peak $16-28^{\circ}$, the presence of $\mathrm{SiO}_{2}$ compounds was indicated (Ates and Akgül, 2016). At peak $30.71^{\circ}$, there was dolomite recorded, while at peak $22.77^{\circ}$ referred to clinoptilolite compounds (Saraya and Thabet, 2018). Some peaks were lost and new peaks appeared after thermal activation. The smectite phase appeared, namely quartz at peak $26.30^{\circ}$ while clinoptilolite remained and the peak indicated dolomite reduced.

The FTIR spectra of natural zeolite and thermal activated zeolite are shown in Figure 3 to identify the change of functional groups after thermal activation. The main band of natural zeolite showed in $1002.79 \mathrm{~cm}^{-1}$ which refers to vibrations of Si-O-Si and Si-O-Al (Nizami et al., 2016). The band at $1635 \mathrm{~cm}^{-1}$ indicated the presence of water molecule in zeolite (Nikolov, Nugteren, and Rostovsky, 2020). In the range of the bands $500-551 \mathrm{~cm}^{-1}$, it can be assigned to the vibrations of different $\mathrm{Al}-\mathrm{O}$ and $\mathrm{Si}-\mathrm{O}$. The band $792.57 \mathrm{~cm}^{-1}$ showed the exchangeable cations due to the pseudocrystallinic vibrations (Ates, 2018). In turn, the band at $\sim 3400 \mathrm{~cm}^{-1}$ is confirmed to groups of $\mathrm{Si}-\mathrm{OH}$ and $\mathrm{H}-\mathrm{O}-\mathrm{H}$, there was hydrogen

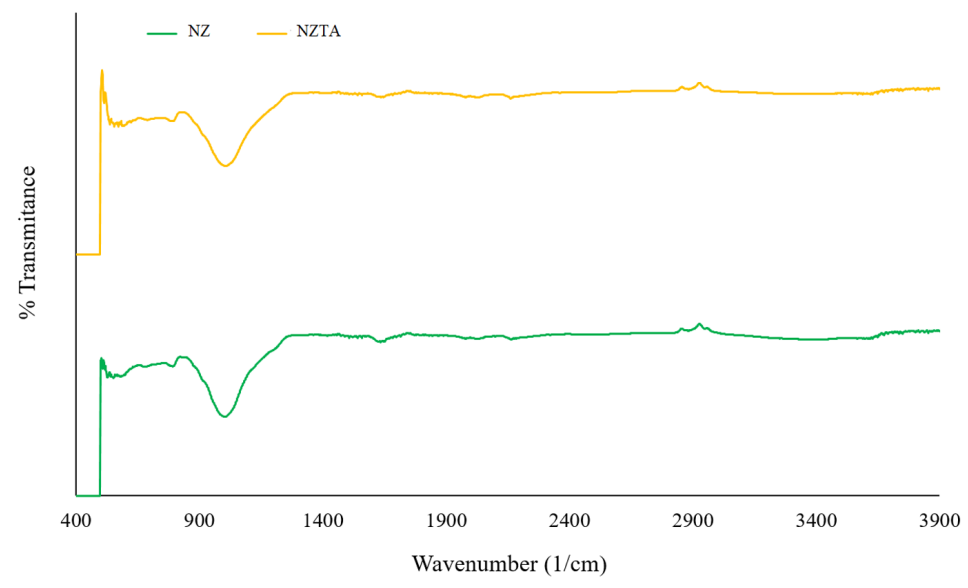

Figure 3. FTIR spectra of NZ and NZTA 
bonding of the molecule of water to surface oxygen. After thermal activation on natural zeolite, there were degradations of some groups according to the bands appearing. The band along 700s $\mathrm{cm}^{-1}$ and the band at $3400 \mathrm{~cm}^{-1}$ disappeared from the spectra that are indicated to the loss of exchangeable cations and water molecules during the thermal activation (Ates, 2018).

\section{Composition gas affected by temperature and catalyst}

An increased gas composition is generally produced from the gasification process (Figure 4). A greater amount of carbon monoxide is produced from hydrogen and methane. Carbon monoxide is formed from a partial combustion reaction after going through the combustion phase. Carbon reacts with the oxygen supplied at the bottom of the reactor for the combustion process to produce carbon dioxide. The amount of oxygen that has been used is reduced so that it switches to partial combustion to produce carbon monoxide.

The increase in temperature affects the composition of the gas produced. The carbon monoxide content is greater at higher temperatures than hydrogen. Apart from the combustion process, carbon monoxide is formed from the reaction of carbon from feeds with carbon dioxide that has been produced previously from the combustion zone. Carbon monoxide can also form from the reaction of carbon and steam originating from the biomass itself. Palm empty fruit bunches in this study have the water content of up to $70 \%$. Heating before being fed to the gasifier can reduce the water content to $20 \%$. In the drying zone, the water that turns into steam reacts with carbon to produce carbon monoxide, hydrogen and carbon dioxide. The best temperature of the gasification process is based on the composition of the gas produced at $550^{\circ} \mathrm{C}$. Gasification under these conditions produced $\mathrm{CH}_{4}, \mathrm{CO}, \mathrm{H}_{2}$, and $\mathrm{CO}_{2}$ corresponding to $22.64 \%, 29.22 \%, 3.4 \%$, and $1.1 \%$, respectively. The gasification in this experiment is included in low-temperature gasification. Increasing the temperature will encourage a reaction to the formation of hydrocarbons which will increase the hydrogen concentration and decrease methane (Anyaoha et al., 2018).

Natural zeolite is used as catalyst in the form of powder. It is used directly together with raw materials. The amount of catalyst was $12.5 \%$ of the total biomass. The volume percentage of carbon monoxide and methane tends to increase at $450-550^{\circ} \mathrm{C}$. Zeolite increases the amount of syngas by catalytic cracking process. Catalytic cracking is characterized by heavy hydrocarbons contained in PEFB broken down into smaller molecules when using zeolite. The content of $\mathrm{SiO}_{2} /$ $\mathrm{Al}_{2} \mathrm{O}_{3}$ affects the yield of the gas produced specifically in carbon monoxide (Guda and Toghiani, 2016). These compounds play a role in good heat transfer to convert raw materials into gas so that syngas has formed even at low temperatures. The reactivity decreases during the process; therefore, it is more stable and the cation can last longer. Then, it accumulates at the active site of the catalyst which causes the buildup of carbon products. Zeolite and PEFB yield the $\mathrm{H}^{+}$ions to be exchanged according to acid-base reactions. When this exchange is neutral, the $\mathrm{H}$ atom unites to form hydrogen. In other words, in addition to accelerating the reaction, zeolite as a catalyst also influences the composition of the gas produced by increasing hydrogen. The hydrogen will then react with carbon monoxide as a result of the combustion reaction. The hydrogen reaction producing methane is called the methane reaction.

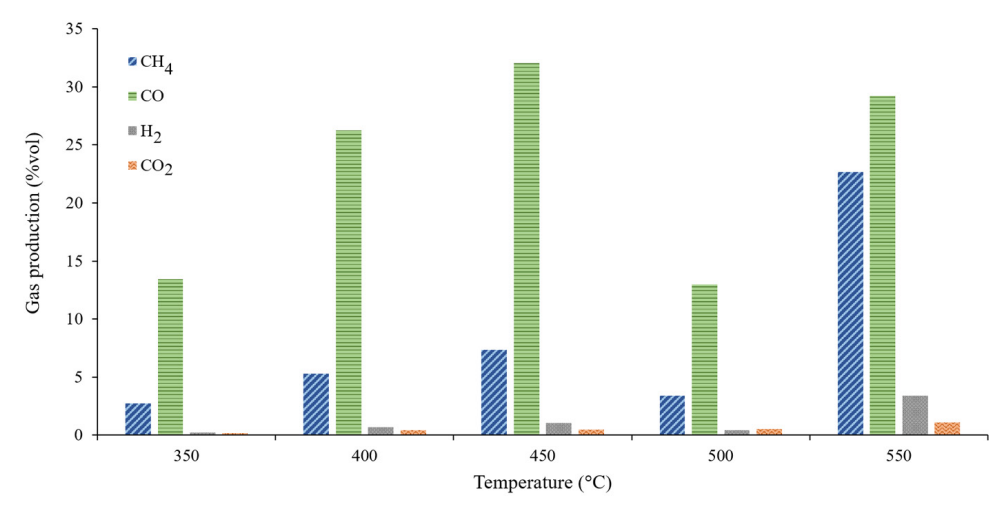

Figure 4. The effect of gasification temperature in the producer gas 


\section{Combustible ratio}

The combustible gas ratio states the amount of combustible gas produced compared to the gas that cannot be combusted. The non-combustible gases that emerge are $\mathrm{CO}_{2}, \mathrm{O}_{2}$, and $\mathrm{N}_{2}$. The highest ratio was obtained at $550^{\circ} \mathrm{C}$ which is 3.4 with the dominant gas being methane and carbon monoxide (Figure 5). The lowest ratio was obtained at $350^{\circ} \mathrm{C}$, which is suspected because the gasification temperature has not been reached. In the combustion and pyrolysis stages, carbon dioxide is formed from the reaction of carbon from biomass with oxygen as a gasification agent (Chun and Song, 2019). Through this ratio, the syngas quality and gas combustion rate can be seen for the next process. The oxygen at the end of the gas product is a residue from the gasification agent, as well as nitrogen which is a disadvantage of using this kind of agent.

\section{$\mathrm{H}_{2} / \mathrm{CO}$ ratio}

The ratios between $\mathrm{H}_{2}$ and $\mathrm{CO}$ are presented in Figure 6. The highest ratio was obtained at a gasification temperature of $550^{\circ} \mathrm{C} 0.12$. This ratio is relatively small but it does not mean that the gas produced contains a lot of carbon dioxide, as stated by Trubetskaya et al. (2019). In our study, the hydrogen produced was $3 \%$ vol while carbon monoxide was nearly $30 \%$ vol. There is a considerable difference which causes a low ratio, which indicates that the gas which is mostly formed is carbon dioxide (Rozas et al., 2019). The increase in the $\mathrm{H}_{2} / \mathrm{CO}$ ratio is influenced by temperature. At $450^{\circ} \mathrm{C}$, the average ratio is 0.5 while at $500^{\circ} \mathrm{C}$ the ratio is doubled.

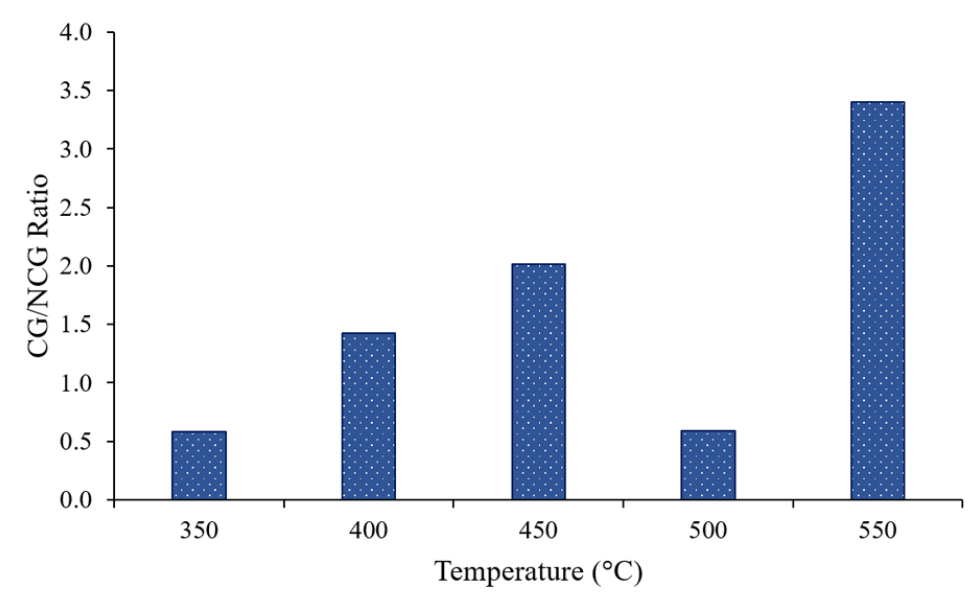

Figure 5. The effect of gasification temperature in the produced gas

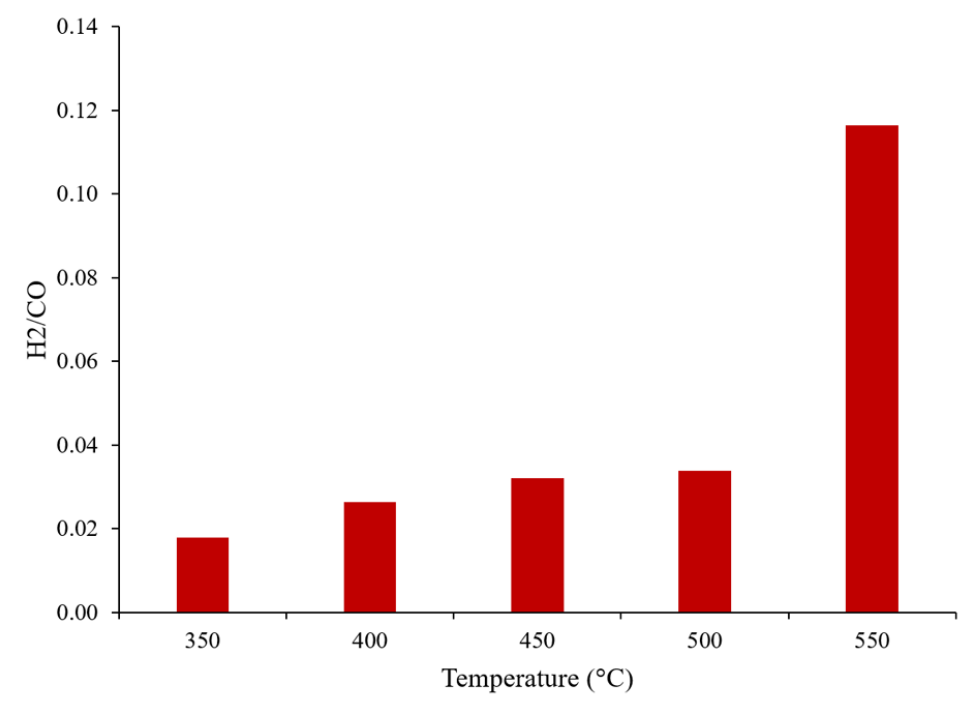

Figure 6. Ratio of $\mathrm{H}_{2} / \mathrm{CO}$ in the produced gas 
Table 2. Characterization of producer gas

\begin{tabular}{|c|c|c|c|c|}
\hline Temperature $\left({ }^{\circ} \mathrm{C}\right)$ & LHV gas $\left({\left.\mathrm{MJ} / \mathrm{Nm}^{-3}\right)}\right)$ & HHV gas $\left(\mathrm{MJ} / \mathrm{Nm}^{-3}\right)$ & CGE $(\%)$ & CCE $(\%)$ \\
\hline 350 & 2.69 & 2.81 & 18.07 & 38.79 \\
\hline 400 & 5.28 & 5.51 & 35.43 & 75.97 \\
\hline 450 & 6.78 & 7.10 & 45.48 & 94.61 \\
\hline 500 & 2.90 & 3.05 & 19.49 & 40.17 \\
\hline 550 & 12.17 & 13.13 & 81.65 & 95.74 \\
\hline
\end{tabular}

\section{HHV, LHV, CGE, and CCE producer gas}

The heating values (HHV and LHV) at each gasification temperature are calculated from the gas produced by equations 1 and 2 (Table 2). The highest heating value of the gas produced is obtained at $550^{\circ} \mathrm{C}$. Likewise, the cold gas efficiency (CGE) and carbon conversion efficiency (CCE) are also highest at $550^{\circ} \mathrm{C}$.

\section{CONCLUSION}

Raw material characterization shows that PEFB is suitable for gasification. The thermal activation of natural zeolite does not show significant changes in its structure and functional groups, but significantly shows the effect on the carbon monoxide formation. Overall, temperature affects the PEFB gasification process and the gas produced. Good quality gas is this study produced at $550^{\circ} \mathrm{C}$ with yield of $22.64 \%$ vol $\mathrm{CH}_{4}, 29.22 \%$ vol $\mathrm{CO}$, and $3.4 \%$ mole $\mathrm{H}_{2}$. The carbon conversion efficiency and cold gas efficiency reached the range of $38-95 \%$, and $18-81 \%$, respectively.

\section{Acknowledgements}

The authors are grateful for financial support in overall research to the Ministry of Research and Higher Education of Republic Indonesia through the research grant of Pendidikan Magister menuju Doktor untuk Sarjana Unggul (PMDSU) batch IV scholarship and PT. Pupuk Sriwidjaja Palembang as an industrial company for the analysis support.

\section{REFERENCES}

1. Afriyanti D., Kroeze C., and Saad A. 2016. Indonesia palm oil production without deforestation and peat conversion by 2050. Science of the Total Environment, 557-558, 562-570.
2. Amrullah A. and Matsumura Y. 2018. Supercritical water gasification of sewage sludge in continuous reactor. Bioresource Technology, 249, 276-283.

3. Anyaoha K.E., Sakrabani R., Patchigolla K., and Mouazen A.M. 2018. Critical evaluation of oil palm fresh fruit bunch solid wastes as soil amendments: Prospects and challenges. Resources, Conservation and Recycling, 136, 399-409.

4. Ates A. 2018. Effect of alkali-treatment on the characteristics of natural zeolites with different compositions. Journal of Colloid and Interface Science, 523, 266-281.

5. Ates A. and Akgül G. 2016. Modification of natural zeolite with naoh for removal of manganese in drinking water. Powder Technology, 287, 285-291.

6. Cabuk B., Duman G., Yanik J., and Olgun H.. 2019. Effect of fuel blend composition on hydrogen yield in co-gasification of coal and non-woody biomass. International Journal of Hydrogen Energy, 45(5), 3435-3443.

7. Chang G., Yan X., Qi P., An M., Hu X., and Guo Q. 2018. Characteristics of reactivity and structures of palm kernel shell (PKS) biochar during CO2/H2O mixture gasification." Chinese Journal of Chemical Engineering, 26(10), 2153-2161.

8. Chew J.J., Soh M., Sunarso M., Yong S.T., Doshi V., and Bhattacharya S. 2020. Gasification of torrefied oil palm biomass in a fixed-bed reactor: Effects of gasifying agents on product characteristics. Journal of the Energy Institute, 93(2), 711-722.

9. Faizal M. 2017. Utilization biomass and coal mixture to produce alternative solid fuel for reducing emission of green house gas. International Journal on Advanced Science, Engineering and Information Technology, 7(3), 950-956.

10. Guda V.K. and Toghiani H. 2016. Altering bio-oil composition by catalytic treatment of pine wood pyrolysis vapors over zeolites using an auger - packed bed integrated reactor system. Biofuel Research Journal, 3(3): 448-457.

11. Gurevich Messina L.I., Bonelli P.R., and Cukierman A.L. 2017. In-situ catalytic pyrolysis of peanut shells using modified natural zeolite. Fuel Processing Technology, 159, 160-167.

12. Hossain, M.M. 2018. Promotional effects of Ce on $\mathrm{Ni}-\mathrm{Ce} / \mathrm{\Gamma A} 12 \mathrm{O} 3$ for enhancement of $\mathrm{H} 2$ in 
hydrothermal gasification of biomass. International Journal of Hydrogen Energy, 43, 6088-6095.

13. Khanday, Ahmad W., Kabir G., and Hameed B.H. 2016. Catalytic pyrolysis of oil palm mesocarp fibre on a zeolite derived from low-cost oil palm ash. Energy Conversion and Management, 127, 265-272.

14. Kodir A., Hartono D.M., Haeruman H., and Mansur I. 2017. Integrated post mining landscape for sustainable land use: A case study in South Sumatera, Indonesia. Sustainable Environment Research, 27(4), 203-213.

15. Kwiencinska A., Iluk T., and Kochel M. 2016. Utilization of aqueous-tar condensates formed during gasification. Journal of Ecological Engineering, 17(5), 132-137.

16. Li Y.H. and Chen H.H. 2018. Analysis of syngas production rate in empty fruit bunch steam gasification with varying control factors. International Journal of Hydrogen Energy, 43(2), 667-675.

17. Liew R.K., Nam W.L., Chong M.Y., Phang X.Y., Su M.H., Yek P.N.Y., Ma N.L., Cheng C.K., Chong C.T., and Lam S.S. 2018. Oil palm waste: An abundant and promising feedstock for microwave pyrolysis conversion into good quality biochar with potential multi-applications. Process Safety and Environmental Protection, 115, 57-69.

18. Mahlia T.M.I., Ismail N., Hossain N., Silitonga A.S., and Shamsuddin A.H. 2019. Palm oil and its wastes as bioenergy sources: A comprehensive review. Environmental Science and Pollution Research, 26, 14849-14866.

19. Miandad R., Barakat M.A., Rehan M., Aburiazaiza A.S., Ismail I.M.I., and Nizami A.S. 2017. Plastic waste to liquid oil through catalytic pyrolysis using natural and synthetic zeolite catalysts. Waste Management, 69, 66-78.

20. Monir M.U., Aziz A.A., Kristanti R.A., and Yousuf A. 2018. Co-gasification of empty fruit bunch in a downdraft reactor: A pilot scale approach. Bioresource Technology Reports, 1, 39-49.

21. Naghizadeh M., Taher M.A., Behzadi M., and Moghaddam F.H. 2017. Preparation a novel magnetic natural nano zeolite for preconcentration of cadmium and its determination by ETAAS. Environmental Nanotechnology, Monitoring and Management, 8, 261-267.

22. Nikolov A., Nugteren H., and Rostovsky I. 2020. Optimization of geopolymers based on natural zeolite clinoptilolite by calcination and use of aluminate activators. Construction and Building Materials, 243, 118257.

23. Nizami A.S., Ouda O.K.M., Rehan M., El-Maghraby A.M.O., Gardy J., Hassanpour A., Kumar S., and Ismail I.M.I. 2016. The potential of saudi arabian natural zeolites in energy recovery technologies. Energy, 108, 162-171.
24. Ooi Z.X., Teoh Y.P., Kunasundari B., and Shuit S.W. 2017. Oil palm frond as a sustainable and promising biomass source in Malaysia: A review. Environmental Progress \& Sustainable Energy.

25. Patra T.K. and Sheth P.N. 2015. Biomass gasification models for downdraft gasifier: A state-of-theart review. Renewable and Sustainable Energy Reviews, 50, 583-593.

26. Pino N., Buitrago-Sierra R., and López D. 2019. Conversion of biomass-derived furanics to fuelrange hydrocarbons: Use of palm oil empty fruit bunches. Waste and Biomass Valorization, 11, 565-577.

27. Putrasari Y., Praptijanto A., Santoso W.B., and Lim O. 2016. Resources, policy, and research activities of biofuel in Indonesia: A review. Energy Reports, 2, 237-245.

28. Rozas R., Escalona N., Sepulveda C., Leiva K., Chimentao R.J., Garcia R., and Fierro J.L.G.. 2019. Catalytic gasification of pine-sawdust: Effect of primary and secondary catalysts. Journal of the Energy Institute, 92(6), 1727-1735.

29. Sarafraz M.M., Safaei M.R., Jafarian M., Goodarzi M., and Arjomandi M.. 2019. High Quality Syngas production with supercritical biomass gasification integrated with a water-gas shift reactor. Energies, 12(13), 2591.

30. Saraya M.E.I. and Thabet M.S. 2018. Characterization and evaluation of natural zeolite as a pozzolanic material. Al-Azhar Bulletin of Science, 29, 17-34.

31. Sazali S.N., Al-attab K.A., and Zainal Z.A. 2019. Gasification enhancement and tar reduction using air fogging system in a double walled downdraft biomass gasifier. Energy, 186, 115901.

32. Shahputra M.A. and Zen Z. 2018. Positive and negative impacts of oil palm expansion in indonesia and the prospect to achieve sustainable palm oil. IOP Conference Series: Earth and Environmental Science, 122.

33. Shayan E, Zare V., and Mirzaee I. 2018. Hydrogen production from biomass gasification; A theoretical comparison of using different gasification agents. Energy Conversion and Management, 159, 30-41.

34. Sihombing J.L., Pulungan A.N., Herlinawati H., Yusuf M., Gea S., Agusnar H., Wirjosentono B., and Hutapea Y.A. 2020. Characteristic and catalytic performance of Co and Co-Mo metal impregnated in sarulla natural zeolite catalyst for hydrocracking of MEFA rubber seed oil into biogasoline fraction. Catalysts, 10(1), 121.

35. Sivasangar S., Zainal Z., Salmiaton A., and TaufiqYap Y. H.. 2015. Supercritical water gasification of empty fruit bunches from oil palm for hydrogen production. Fuel, 143, 563-569.

36. Soria-Verdugo A., Berg L.V., Serrano D., Hochenauer C., Scharler R., and Anca-Couce A. 2019. 
Effect of bed material density on the performance of steam gasification of biomass in bubbling fluidized beds. Fuel, 257, 116118.

37. Trubetskaya A., Leahy J.J., Yazhenskikh E, Müller M, Layden P., Johnson R., Ståhl K., and Monaghan R.F.D. 2019. Characterization of woodstove briquettes from torrefied biomass and coal. Energy, 853-865.

38. Umar M.S., Urmee T., and ennings P. 2017. A policy framework and industry roadmap model for sustainable oil palm biomass electricity generation in Malaysia. Renewable Energy, 128, 275-284.

39. Umeda K., Nakamura S., Lu D., and Yoshikawa K. 2019. Biomass gasification employing low-temperature carbonization pretreatment for tar reduction. Biomass and Bioenergy, 126, 142-149.

40. Yoo H., Park S., Seo Y., and Kim K. 2019. Applicability assessment of empty fruit bunches from palm oil mills for use as bio-solid refuse fuels. Journal of Environmental Management, 234, 1-7.
41. You S., Tong H., Armin-Hoiland J, Tong Y.W., and Wang C.H. 2017. Techno-economic and greenhouse gas savings assessment of decentralized biomass gasification for electrifying the rural areas of Indonesia. Applied Energy, 208, 495-510.

42. Zhang Lu., Wu W., Zhang Y., and Zhou X. 2018. Clean Synthesis gas production from solid waste via catalytic gasification and reforming technology. Catalysis Today, 318, 39-45.

43. Zhang W., Huang S., Wu S., Wu Y., and Gao J. 2019. Study on the structure characteristics and gasification activity of residual carbon in biomass ashes obtained from different gasification technologies. Fuel, 254, 115699.

44. Zhou L., Yang Z., Tang A., Huang H., Wei D., Yu E., and Lu W. 2019. Steam-gasification of biomass with $\mathrm{CaO}$ as catalyst for hydrogen-rich syngas production. Journal of the Energy Institute, 92(6), 1641-1646. 